\title{
Clonal integration in Phagmites australis mitigates effects of oil pollution on greenhouse gas emissions in a coastal wetland
}

\author{
Qing-Ye Yuan ${ }^{\mathrm{a}, \mathrm{b}}$, Peter Alpert ${ }^{\mathrm{c}}$, Jing An ${ }^{\mathrm{d}, \mathrm{e}}$, Jun-Qin Gao ${ }^{\mathrm{d}}$, Guang-Xuan Han ${ }^{\mathrm{f}}$, Fei-Hai Yu ${ }^{\mathrm{a}, *}$ \\ a Institute of Wetland Ecology \& Clone Ecology/Zhejiang Provincial Key Laboratory of Plant Evolutionary Ecology and Conservation, Taizhou University, Taizhou 318000, China \\ b International Education College, Beijing Vocational College of Agriculture, Beijing 102442, China \\ c Biology Department, University of Massachusetts, Amherst, MA 01003, USA \\ d School of Ecology and Nature Conservation, Beijing Forestry University, Beijing 100083, China \\ e Beijing Songshan National Nature Reserve Administration, Beijing 102115, China \\ ${ }^{\mathrm{f}}$ Key Laboratory of Coastal Environment Processes, Yantai Institute of Coastal Zone Research, Chinese Academy of Sciences, Yantai 264003, China
}

\section{H I G H L I G H T S}

- Oil pollution reduced Phragmites australis production in a coastal wetland.

- Oil pollution increased greenhouse gas emissions from the P. australis wetland.

- Clonal integration in P. australis stressed by oil pollution increased its growth.

- Integration reduced greenhouse gas emissions from the oil-polluted wetland.

\section{A R T I C L E I N F O}

\section{Article history:}

Received 2 April 2020

Received in revised form 18 May 2020

Accepted 3 June 2020

Available online 5 June 2020

Editor: Yifeng Zhang

\section{Keywords:}

Carbon dioxide

Clonal integration

Crude oil contamination

Methane

Nitrous oxide

\section{G R A P H I C A L A B S T R A C T}

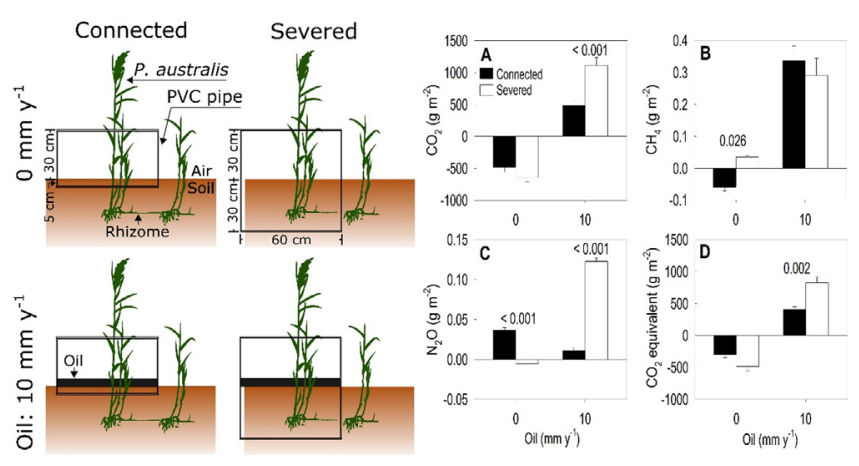

\section{A B S T R A C T}

Clonal integration, i.e., resource sharing within clones, enables clonal plants to maintain biomass production when ramets (asexual individuals) under stress are connected to those not under stress. Oil pollution can strongly reduce biomass production, and connected ramets within clones may experience different levels of oil pollution. Therefore, clonal integration may help plants maintain biomass production despite oil pollution. Because biomass production is often negatively correlated with greenhouse gas emissions, we hypothesized that oil pollution would increase greenhouse gas emissions and that clonal integration would reduce such an effect. We tested these hypotheses in a coastal wetland dominated by the rhizomatous grass Phragmites australis near a major site of oil production in the Yellow River Delta in China. We applied 0, 5, or $10 \mathrm{~mm}$ crude oil per year for two years in plots within stands of $P$. australis and tested effects of severing rhizomes connecting ramets inside and outside a plot (i.e. preventing clonal integration) on biomass production, soil chemistry and greenhouse gas emissions. When severed, ramets inside plots with no added oil produced about $220 \mathrm{~g}$ aboveground biomass $\mathrm{m}^{-2}$ over the second growing season, and plots absorbed about $500 \mathrm{~g}$ total $\mathrm{CO}_{2}$ equivalents $\mathrm{m}^{-2}$. Adding $10 \mathrm{~mm}$ oil per year reduced aboveground biomass by about $30 \%$, and caused plots to emit about $800 \mathrm{~g} \mathrm{CO}_{2}$ equivalents $\mathrm{m}^{-2}$. Leaving ramets connected to those outside plots eliminated the negative effects of oil pollution on biomass production, and caused plots given $10 \mathrm{~mm}$ oil per year to emit about $50 \%$ fewer total $\mathrm{CO}_{2}$ equivalents. We conclude that oil pollution can increase greenhouse gas emissions and clonal integration can reduce the effect

\footnotetext{
* Corresponding author.

E-mail address: feihaiyu@126.com (F.-H. Yu).
} 
of oil pollution on biomass production and greenhouse gas emissions. Our study provides the first experimental evidence that clonal integration in plants can reduce greenhouse gas emissions.

(c) 2020 Elsevier B.V. All rights reserved.

\section{Introduction}

Connected ramets (i.e., asexual individuals) within clones often transport and share resources between ramets through the connecting stems or roots (de Kroon and van Groenendael, 1997; He et al., 2011; Dong et al., 2015). When connected ramets experience contrasting levels of stress, resource sharing via such clonal integration can increase their survival and growth (Song et al., 2013; Wang et al., 2017; Lin et al., 2018). This has been shown for a wide variety of stress, including low nutrient availability (Alpert, 1991; Hutchings and Wijesinghe, 2008; He et al., 2010), drought (Alpert and Mooney, 1986; Zhang et al., 2008), shade (Alpert, 1999; Xu et al., 2010), hypoxia (Li et al., 2015), high salinity (Salzman and Parker, 1985), high concentrations of toxic metals (Roiloa and Retuerto, 2012; Luo et al., 2017), sand burial (Yu et al., 2004) and wind erosion (Yu et al., 2008).

Crude oil can be highly toxic to plants (Lin and Mendelssohn, 2012; Judy et al., 2014). Plants in coastal wetlands are thus increasingly subject to stress from the deposition of crude oil from on- and off-shore leaks and spills (Silliman et al., 2009; Mendelssohn et al., 2012). For example, addition of oil has been experimentally shown to decrease the photosynthetic capacity (Dowty et al., 2001) and aboveground primary production (Judy et al., 2014) of Phragmites australis, which is a dominant species in coastal wetlands on multiple continents (Han et al., 2012; Eller et al., 2017). Coastal wetlands often show fine-scale, natural patchiness in salinity and soil oxygen (Pennings et al., 2005; Wilson et al., 2015), and clonal integration between ramets within clones in wetlands is known to increase the ability of plants to survive and grow in patches of high salinity or low oxygen when these ramets are connected to other ramets in more favorable patches (Shumway, 1995; Amsberry et al., 2000). However, the ability of clonal integration to increase the capacity of plants to maintain growth in wetlands subject to patchy deposition of oil is untested.

Greenhouse gas emissions are negatively correlated with plant productivity in a variety of natural systems, mainly because net productivity requires net uptake of $\mathrm{CO}_{2}$ (Yavitt, 1997; Brix et al., 2001; Liu and Greaver, 2009; Snyder et al., 2009; Merbold et al., 2014; Mo et al., 2015). Natural and anthropogenic stress and disturbance that reduce productivity can lead to a reduction of $\mathrm{CO}_{2}$ absorption through photosynthesis and thus increase net emissions of greenhouse gases (Fahey et al., 2005). Alleviation of stress can decrease net emissions, as after major precipitation events in arid systems (Huxman et al., 2004). By reducing plant biomass production, oil pollution might thus increase greenhouse gas emissions in coastal wetlands. By mitigating effects of oil pollution on plant biomass production, clonal integration might also mitigate effects of oil pollution on emissions of greenhouse gases. No previously published studies have tested either of these possibilities.

We therefore conducted a field experiment to test two hypotheses: 1) clonal integration in clonal plants can enable them to maintain biomass production when subjected to oil pollution, and 2) clonal integration can mitigate the effect of oil pollution on greenhouse gas emissions. We used natural stands of one of the most widespread and abundant clonal plant species and worked at a site in a major coastal wetland subject to oil deposition. We measured emissions of the three gases that contribute most to global warming (i.e., $\mathrm{CO}_{2}, \mathrm{CH}_{4}$, and $\mathrm{N}_{2} \mathrm{O}$; IPCC, 2014), and soil chemistry that might help elucidate mechanisms underlying the effects. We specifically predicted that 1 ) applying oil to soil would decrease biomass production and increase greenhouse gas emissions, and that 2) both the effects of oil application on biomass production and greenhouse gas emissions would be smaller when plants within oiled areas were left connected to plants outside areas (i.e., allowing clonal integration) than when connections were severed (i.e., preventing clonal integration).

\section{Materials and methods}

\subsection{Site and species}

The experiment was conducted in a seasonal wetland at the Yellow River Delta Coastal Wetland Ecology Research Station $\left(37^{\circ} 45^{\prime} 50^{\prime \prime} \mathrm{N}\right.$, $118^{\circ} 59^{\prime} 24^{\prime \prime} \mathrm{E}$ ) of the Yantai Institute of Coastal Zone Research of the Chinese Academy of Sciences. The station is located about $16 \mathrm{~km}$ from the mouth of the Yellow River at an elevation of 0 to $4 \mathrm{~m}$. Much of the delta had been contaminated with crude oil from the Shengli Oil Field, the second biggest oilfield in China; levels of contamination were in the low to medium range of values reported from other deltas (Yang et al., 2008; Kuenzer et al., 2014). The Yellow River Delta is one of the largest and most dynamic estuarine areas in the world (Xu et al., 2004) and provides an important over-wintering and breeding area for birds (Cui et al., 2009).

The wetland has a warm, continental, monsoon climate with a hot, rainy summer, a cold, dry winter, and a mean annual frost-free period of 142 days (Xie et al., 2011). The mean temperature is $12.9^{\circ} \mathrm{C}$, with an all-time high of $41.9^{\circ} \mathrm{C}$ and an all-time low of $-23.3^{\circ} \mathrm{C}$. Mean annual precipitation is $594 \mathrm{~mm}$, of which nearly 70\% falls from May through September. About $55 \%$ of the wetland is covered with natural vegetation (Wang et al., 2012), much of which is strongly dominated by Phragmites australis. Other common plant species include Suaeda heteroptera Kitag., Sonchus brachyotus DC. and Cynanchum chinense R. Br. The area used for this study is seasonally inundated, mainly after heavy rainfalls during mid-July to mid-August and often to a depth of $<5 \mathrm{~cm}$ (Han et al., 2012). Temperatures during the study, in 2014 and 2015 (Fig. S1), were close to mean values; precipitation was close to mean values in 2015 but about half of normal in 2014 (Fig. S1).

P. australis, a large helophytic grass common in freshwater to brackish marshes in temperate and tropical regions worldwide, is one of the most productive and widespread wetland plant species (Haslam, 1969; Clevering and Lissner, 1999; Amsberry et al., 2000; Minchinton and Bertness, 2003; Lambertini et al., 2008; Saleem et al., 2019). The species spreads vegetatively via horizontal, perennial rhizomes that produce annual shoots. Rhizomes can grow $>3 \mathrm{~m}$ in one growing season (Martin and Zallinger, 1972). Clonal integration in P. australis can increase its ability to grow into unfavorable habitats (Amsberry et al., 2000).

In the Yellow River Delta, $P$. australis usually initiates new shoots during late March to early April (Han et al., 2012). Shoots can reach a height of $1.5 \mathrm{~m}$ by the peak of the growing season in early July to midAugust. Terminal inflorescences develop during late summer to early autumn, in August and September. Seeds mature by late autumn, in October. Shoots die at the end of the growing season.

\subsection{Experimental design}

Within the study area, we selected six uniform patches of $P$. australis as blocks. Six circular plots, each $60 \mathrm{~cm}$ in diameter, were randomly located within each block, with the constraint that plots were at least $2 \mathrm{~m}$ apart to minimize interference between treatments. One plot in each 
block was randomly assigned to each of six treatments, two severance treatments (rhizomes severed at the edge of the plot or left connected) crossed with three oil treatments (annual application of 0,5 , or $10 \mathrm{~mm}$ of crude oil; Fig. 1). Amounts of oil were chosen to be similar to those used in previous studies of effects of oil on $P$. australis (Dowty et al., 2001; Ji et al., 2007; Nie et al., 2010; Judy et al., 2014).
For the severance treatment (preventing clonal integration), we dug a narrow trench $30 \mathrm{~cm}$ deep around the perimeter of each plot and severed all rhizomes that crossed the trench, i.e., those connecting plants inside and outside the plot (Fig. 1). We then inserted a plastic pipe with a diameter and height of $60 \mathrm{~cm}$ into the trench, so that the pipe extended $30 \mathrm{~cm}$ below and $30 \mathrm{~cm}$ above the soil surface, filling the trench

\section{Connected}

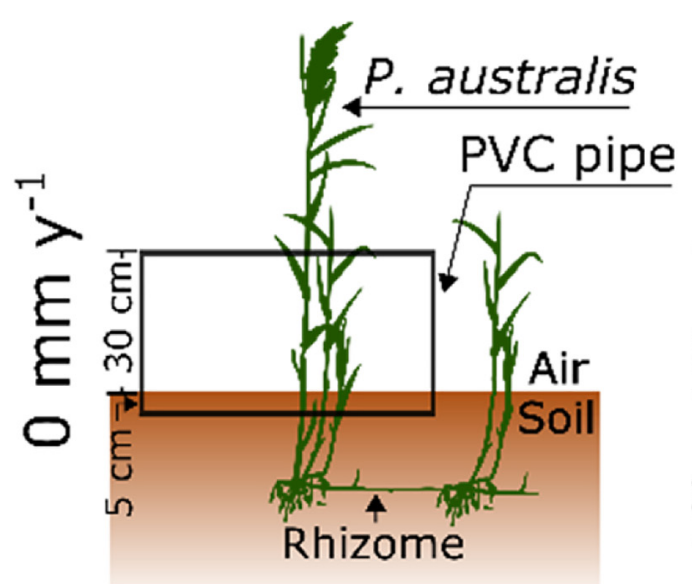

Severed
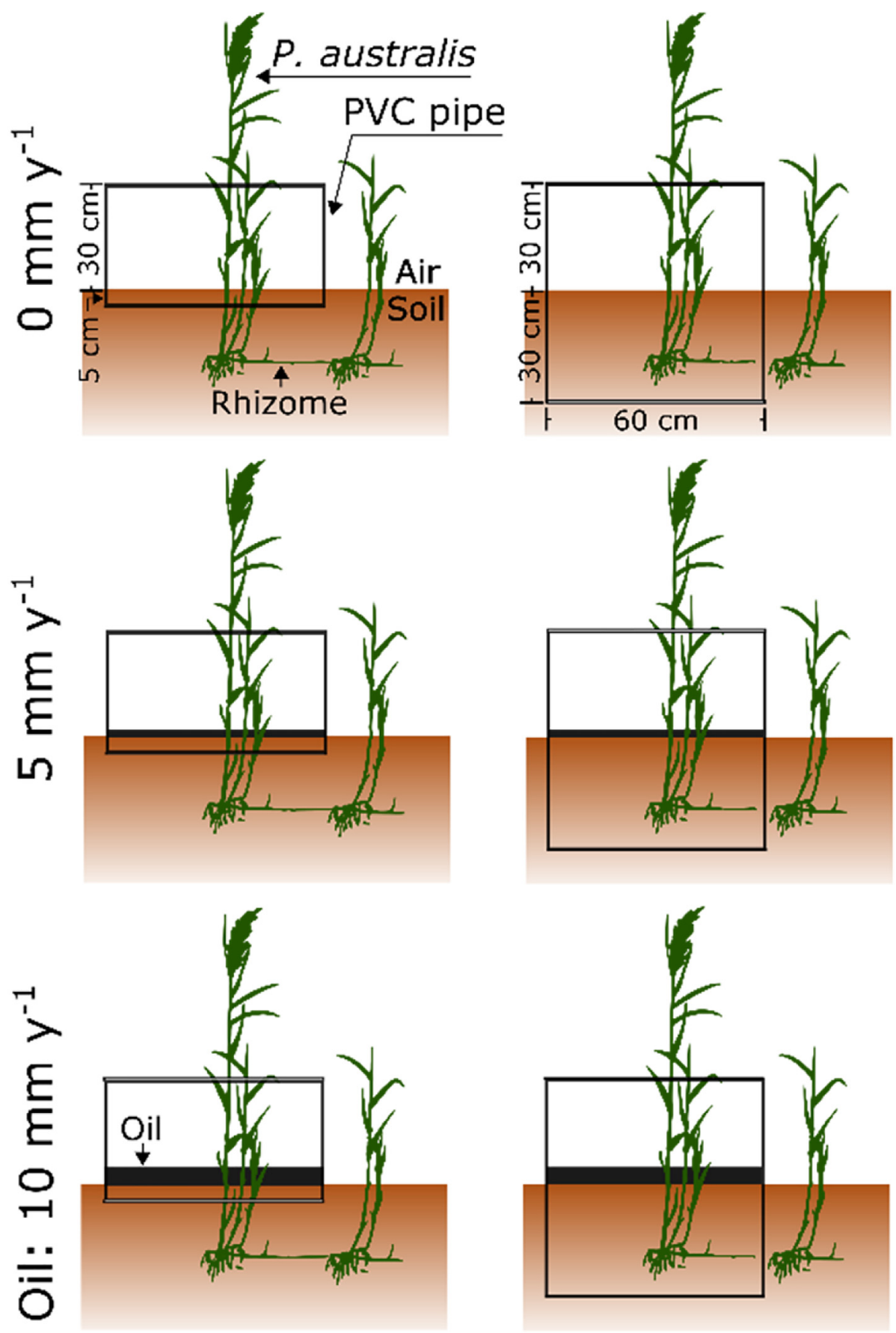

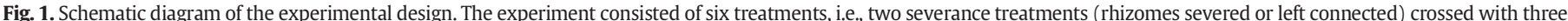

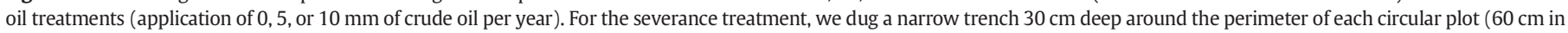

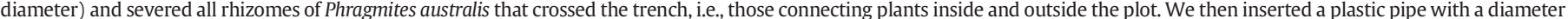

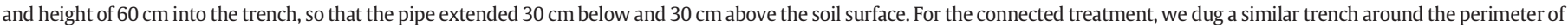

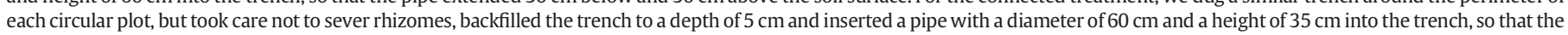
pipe extended just $5 \mathrm{~cm}$ below but again $30 \mathrm{~cm}$ above the soil surface. 
and enclosing the plot. The depth of the pipe was chosen to be greater than that of the rhizomes of $P$. australis, which were mostly $15-20 \mathrm{~cm}$ below the soil surface (Fig. 1). The height of the pipe was chosen to prevent any escape of oil. For the connected treatment (allowing clonal integration), we dug a similar trench around the perimeter of each plot, but took care not to sever rhizomes, backfilled the trench to a depth of $5 \mathrm{~cm}$, and inserted a pipe with a diameter of $60 \mathrm{~cm}$ and a height of $35 \mathrm{~cm}$ into the trench, so that the pipe extended just $5 \mathrm{~cm}$ below but again $30 \mathrm{~cm}$ above the soil surface (Fig. 1). Pipes were placed on 28 June 2014 and oil applied on 29 June 2014 and on 13 May 2015. Dates of application were planned for the start of the growing season each year; the first application was delayed for logistical reasons. Oil was provided by Shengli Oil Field.

\subsection{Growth measurements}

The number of live shoots in each plot was counted approximately monthly from June to October 2014 and May to October 2015. Shoots were then harvested near the end of each growing season, on 25 October 2014 and on 24 October 2015; the timing of the harvests was intended to provide a reasonable measurement of aboveground biomass with as little effect as possible on overwinter storage in rhizomes. Shoots were separated into leaves and stems, dried at $65{ }^{\circ} \mathrm{C}$ for at least $48 \mathrm{~h}$, and weighed. In 2015, the litter in each plot was also collected, dried, and weighed. Some plots had very small amounts of dead, standing shoots of $P$. australis or of aboveground biomass of other species. Both were harvested and dried, but excluded from analyses.

\subsection{Gas measurements}

Net fluxes of $\mathrm{CO}_{2}$ and $\mathrm{CH}_{4}$ were measured in the 0 - and $10-\mathrm{mm}$ oil treatments twice a month from 15 June to 15 October 2015. Net flux of $\mathrm{N}_{2} \mathrm{O}$ was similarly measured from 15 July to 15 October 2015 . Resources did not permit analysis of emissions from the $5 \mathrm{~mm}$ oil treatment. To start each round of measurement, eight transparent (transmission of visible light $>90 \%$ ), cylindrical chambers, each $58 \mathrm{~cm}$ in diameter by $1 \mathrm{~m}$ high, were set atop the pipes surrounding the eight 0 - and $10-\mathrm{mm}$ oil plots in the first two blocks. An airtight seal between each chamber and pipe was created with a water-filled groove around the top of each pipe. The combined height of pipe and chamber, $1.3 \mathrm{~m}$, allowed enclosure of all the plants in a plot. Two electrical fans in each chamber ensured rapid mixing of the air inside. Temperature was monitored with a digital probe thermometer. To measure change in air composition over time, five air samples were collected from each chamber $10 \mathrm{~min}$ apart with a $100 \mathrm{~mL}$ syringe and individually stored in sealed, airtight bags (Delin, Dalian, Liaoning Province, China) for later analysis in the laboratory. After that, the eight chambers were moved to the next two blocks and 40 air samples from the eight 0 - and 10$\mathrm{mm}$ oil plots were collected using the same method. This procedure was repeated again so that 40 air samples were also collected from the eight 0 - and $10-\mathrm{mm}$ oil plots in the last two blocks. Measurements were completed between 8:30 and 11:30 am.

Temperature inside the chamber varied greatly between measurement dates (from $39.0^{\circ} \mathrm{C}$ on 31 July to $15.4^{\circ} \mathrm{C}$ on 15 October), but little within dates (from $6.3^{\circ} \mathrm{C}$ on 31 July to $0.1{ }^{\circ} \mathrm{C}$ on 15 October), and very little between samples from the same plot on the same date (generally $<1.0{ }^{\circ} \mathrm{C}$ ). Data on solar radiation collected by the research station showed that gas sampling was mostly conducted on sunny days (Fig. S3B).

Air samples were analyzed with a gas chromatograph (7890A, Agilent Technologies, Inc., Santa Clara, USA) equipped with a hydrogen flame ionization detector to measure $\mathrm{CH}_{4}$ and $\mathrm{CO}_{2}$ and with an electron capture detector to measure $\mathrm{N}_{2} \mathrm{O}$. Fluxes were calculated with the equation (Towprayoon et al., 2005),
$F=\frac{\rho \times 273}{273+T} \times H \times d C / d t$

where $F$ is flux as mass per unit of area per unit of time, $\rho$ is gas density at $0{ }^{\circ} \mathrm{C}$ and $760 \mathrm{~mm} \mathrm{Hg}, T$ is mean air temperature inside the chamber, $H$ is the height of the enclosed airspace, and $d C / d t$ is the slope of the linear regression of concentration on time based on the five samples per plot per date. Sample sets were rejected if $\mathrm{R}^{2}$ for the regression was smaller than 0.90 .

Cumulative emissions of $\mathrm{CO}_{2}, \mathrm{CH}_{4}$, and $\mathrm{N}_{2} \mathrm{O}$ for the growing season were calculated by linear interpolation between measurement dates (D. Liu et al., 2014; S.W. Liu et al., 2014; Mo et al., 2015). To calculate a combined measure of global warming potential, we used the 100-year $\mathrm{CO}_{2}$ equivalencies suggested by IPCC (2014) and assumed that only $\mathrm{CO}_{2}, \mathrm{CH}_{4}$, and $\mathrm{N}_{2} \mathrm{O}$ contributed to warming, giving total $\mathrm{CO}_{2}$ equivalents $=\mathrm{CO}_{2}+28 \mathrm{CH}_{4}+265 \mathrm{~N}_{2} \mathrm{O}$.

\subsection{Soil analysis}

On 25 August 2015, three soil samples each $3 \mathrm{~cm}$ in diameter and 0-20 cm deep were collected at random locations within each plot in the 0 - and $10-\mathrm{mm}$ oil treatments. Samples from the same plot were mixed, sieved through a $2 \mathrm{~mm}$ mesh, and divided into two portions. The first portion was immediately placed on ice, transported to the Institute of Botany of the Chinese Academy of Sciences in Beijing, and stored at $-20{ }^{\circ} \mathrm{C}$ until analysis for $\mathrm{NH}_{4}^{+}-\mathrm{N}$ and $\mathrm{NO}_{3}^{-}-\mathrm{N}$. The second portion was air-dried, ground, re-sieved, and subsampled for analysis of total $\mathrm{C}$ and $\mathrm{N}$ in a CHNOS elemental analyzer (Vario EL III, Elementar Analysensysteme GmbH, Hanau, Germany; Wang et al., 2015). For analysis of $\mathrm{NH}_{4}^{+}-\mathrm{N}$ and $\mathrm{NO}_{3}^{-}-\mathrm{N}$, subsamples were extracted by shaking with $2 \mathrm{M} \mathrm{KCl}$ ( $1: 5$ soil: extractant) for $1 \mathrm{~h}$ followed by colorimetry in a continuous flow analyzer (AA3, Bran Luebbe, Germany; Dongwook et al., 2007; D. Liu et al., 2014; S.W. Liu et al., 2014).

\subsection{Data analysis}

We used four-way, repeated-measure ANOVAs to test the effects of oil addition, rhizome severance, year, and block on aboveground biomass, live shoot density, and aboveground biomass per shoot of $P$. australis. Oil and severance were treated as fixed effects and time as a repeated variable. Three-way ANOVAs were used to test effects of oil, severance, and block on litter mass, cumulative emissions of $\mathrm{CO}_{2}$, $\mathrm{CH}_{4}, \mathrm{~N}_{2} \mathrm{O}$ and total $\mathrm{CO}_{2}$ equivalents, and concentrations of total $\mathrm{C}$, total $\mathrm{N}, \mathrm{NH}_{4}^{+}-\mathrm{N}$, and $\mathrm{NO}_{3}^{-}-\mathrm{N}$ in soil. Measures of growth were transformed to the natural log to meet assumptions of ANOVA. Linear contrasts were used to compare means for severed and connected treatments within each oil treatment when $P$ for the effect of severance or of interaction between severance and oil was $<0.05$. Data were analyzed in SPSS 22.0 (IBM Corp., Armonk, NY, USA).

\section{Results}

\subsection{Plant growth}

Adding oil decreased aboveground biomass of $P$. australis by about one-third when plants in oil patches were severed from plants outside patches, but had little effect on aboveground biomass when plants were left connected to plants outside patches (Fig. 2A, D). Effects of oil and severance on aboveground biomass were greater in the second year, but they were qualitatively similar in both years. Shoot density did not show a consistent response to either oil or severance (Fig. 2B, E; Table 1). Across treatments, shoot density and aboveground biomass were higher in 2015 than in 2014, and shoot density generally increased during each year from the beginning of measurements until September (Fig. S2). Connection enabled plants inside plots to maintain about the 

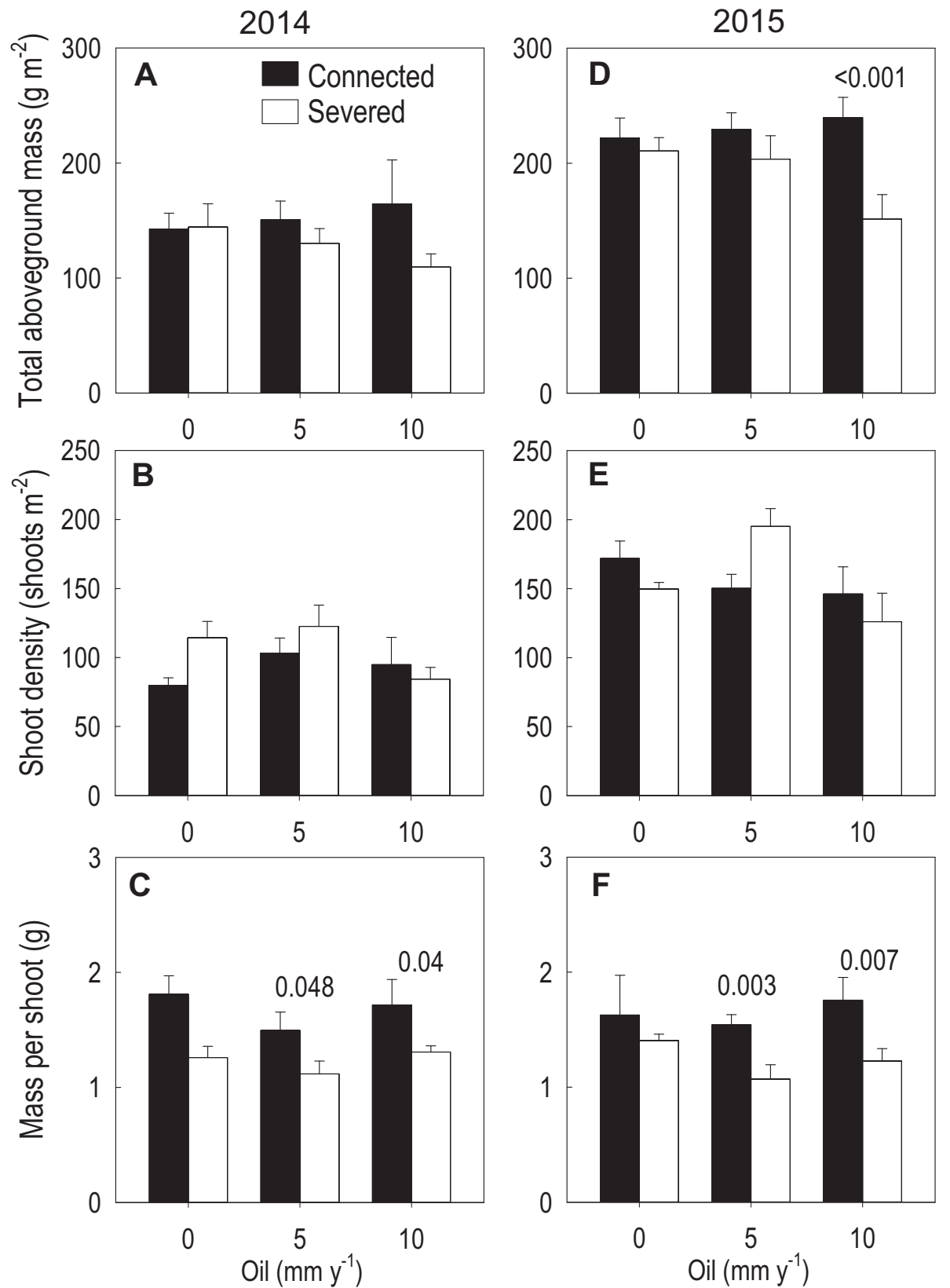

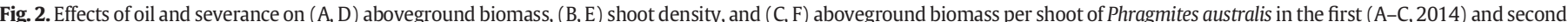

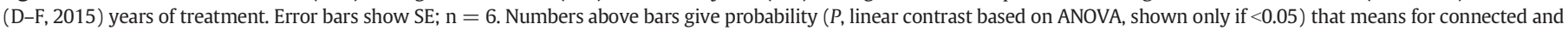
severed treatments did not differ within an oil treatment. See Table 1 for ANOVAs.

same amount of biomass per shoot in plots without and with oil, whereas oil addition decreased biomass per shoot in severed treatments (Fig. 2C, F; Table 1). Treatments did not affect biomass of litter (Table 2; data not shown).

\subsection{Greenhouse gas emissions}

Adding $10 \mathrm{~mm}$ oil per year greatly increased cumulative net emissions of $\mathrm{CO}_{2}$ and $\mathrm{CH}_{4}$ relative to those in plots without added oil (Fig. 3A, B; Table 2: effect of oil). Since $\mathrm{CO}_{2}$ contributed $>95 \%$ of total $\mathrm{CO}_{2}$ equivalents in all treatments, adding oil also greatly increased cumulative net emissions of total $\mathrm{CO}_{2}$ equivalents (Fig. 3D). Plots with no added oil were net sinks for $\mathrm{CO}_{2}\left(-563 \mathrm{~g}\right.$ emissions of $\mathrm{CO}_{2} \mathrm{~m}^{-2}$ from 15 June to 15 October), whereas plots with $10 \mathrm{~mm}$ oil per year were net sources for $\mathrm{CO}_{2}\left(799 \mathrm{~g} \mathrm{~m}^{-2}\right)$. Severing rhizomes connecting plants of $P$. australis inside and outside plots had little effect on emissions of $\mathrm{CO}_{2}$ or of total $\mathrm{CO}_{2}$ equivalents in the absence of oil, but resulted in more than doubled emissions in plots given $10 \mathrm{~mm}$ oil per year, e.g., from 483 to $1116 \mathrm{~g} \mathrm{CO}_{2} \mathrm{~m}^{-2}$ from 15 June to 15 October (Fig. 3A, $D$; Table 2: effect of oil $\times$ severance). Severance increased cumulative emissions of $\mathrm{CH}_{4}$ in plots without added oil, but did not significantly affect them in plots with $10 \mathrm{~mm}$ oil per year (Fig. 3B). There was a strong interactive effect of severance and oil treatments on cumulative emissions of $\mathrm{N}_{2} \mathrm{O}$ (Fig. 3C, Table 2).

Effects of oil and severance treatments on net emissions of $\mathrm{CO}_{2}$ were largely consistent over the growing season (Fig. S3), though the difference between connected and severed treatments in plots given $10 \mathrm{~mm}$ oil per year disappeared from mid-August to mid-September. 
Table 1

Repeated-measure ANOVAs of dry aboveground biomass, shoot density, and biomass per shoot of $P$. australis.

\begin{tabular}{|c|c|c|c|c|c|c|}
\hline & \multicolumn{2}{|c|}{ Shoot density } & \multicolumn{2}{|c|}{$\begin{array}{l}\text { Aboveground } \\
\text { mass }\end{array}$} & \multicolumn{2}{|c|}{ Mass per shoot } \\
\hline & df & $\mathrm{F}$ & df & $\mathrm{F}$ & df & $\mathrm{F}$ \\
\hline Block (B) & 5,25 & 1.0 & 5,25 & 2.0 & 5,25 & 1.5 \\
\hline Oil (O) & 2,25 & $3.4^{\#}$ & 2,25 & 1.3 & 2,25 & 2.3 \\
\hline $\begin{array}{l}\text { Severance } \\
\text { (S) }\end{array}$ & 1,25 & 0.6 & 1,25 & $6.2^{*}$ & 1,25 & $20.0^{* * * *}$ \\
\hline $\mathrm{O} \times \mathrm{S}$ & 2,25 & 1.2 & 2,25 & 2.1 & 2,25 & $3.2^{*}$ \\
\hline Time $(\mathrm{T})$ & 1,25 & $95.0^{* * *}$ & 1,25 & $60.3^{* * *}$ & 1,25 & 0.8 \\
\hline $\mathrm{T} \times 0$ & 2,25 & 0.5 & 2,25 & 0.1 & 2,25 & 0.7 \\
\hline $\mathrm{T} \times \mathrm{S}$ & 1,25 & $3.0^{\#}$ & 1,25 & 0.5 & 1,25 & 1.3 \\
\hline $\mathrm{T} \times \mathrm{B}$ & 5,25 & 0.9 & 5,25 & 1.3 & 5,25 & 1.0 \\
\hline $\mathrm{T} \times \mathrm{O} \times \mathrm{S}$ & 2,25 & $3.1^{\#}$ & 2,25 & 0.4 & 2,25 & $4.1^{*}$ \\
\hline
\end{tabular}

Where $P<0.05$, values of $F$ are in bold. Symbols give $P$ : (no symbol) $>0.1{ }^{\#}<0.1 ;{ }^{*}<0.05$; ${ }^{* *}<0.01 ;{ }^{* * *}<0.001$.

Plots with no added oil remained net sinks for $\mathrm{CO}_{2}$ from mid-June to the end of September, but were net sources in mid-October. Fluxes of $\mathrm{CH}_{4}$ and $\mathrm{N}_{2} \mathrm{O}$ varied greatly over the growing season (Fig. S3).
Net emission of $\mathrm{CO}_{2}$ showed a negative relationship to aboveground biomass of $P$. australis across severance and oil treatments as measured ten days before harvest at the end of the growing season in 2015 (Fig. 4). However, aboveground biomass of $P$. australis explained only a small proportion of variation in emission.

\subsection{Soil chemistry}

Addition of $10 \mathrm{~mm}$ oil per year decreased the concentration of $\mathrm{NO}_{3}^{-}$$\mathrm{N}$ in the soil at $0-20 \mathrm{~cm}$ below the surface by $80-90 \%$ and increased the total concentration of $\mathrm{C}$ more than two-fold, but had little effect on $\mathrm{NH}_{4}^{+}-\mathrm{N}$ or total $\mathrm{N}$ (Fig. 5, Table 2). Severance decreased $\mathrm{NO}_{3}^{-}-\mathrm{N}$ by about half in plots without oil, though this effect was only marginally statistically significant $(P=0.05-0.1)$. In the plots without oil or severance, the concentration of $\mathrm{NH}_{4}^{+}$was about five times greater than that of $\mathrm{NO}_{3}^{-}$.

\section{Discussion}

In treatments where the rhizomes connecting plants of $P$. australis inside and outside a plot were severed, applying oil to a plot decreased plant production as measured by accumulation of aboveground bio-

Table 2

ANOVAs of cumulative emissions of $\mathrm{CO}_{2}, \mathrm{CH}_{4}, \mathrm{~N}_{2} \mathrm{O}$, and total $\mathrm{CO}_{2}$ equivalents, biomass of plant litter, and concentrations of $\mathrm{NH}_{4}^{+}$, $\mathrm{NO}_{3}^{-}$, total $\mathrm{N}$, and total $\mathrm{C}$ in soils in 2015 .

\begin{tabular}{|c|c|c|c|c|c|c|c|c|c|}
\hline & $\mathrm{CO}_{2}$ & $\mathrm{CH}_{4}$ & $\mathrm{~N}_{2} \mathrm{O}$ & $\mathrm{CO}_{2} \mathrm{eq}$ & Litter & $\mathrm{NH}_{4}^{+}$ & $\mathrm{NO}_{3}^{-}$ & Total N & Total C \\
\hline Block & 1.5 & 0.9 & 1.4 & 1.0 & 0.4 & 1.4 & 1.9 & 2.0 & 0.6 \\
\hline Oil (0) & $279.9^{* * * *}$ & $108.5^{* * *}$ & $63.4^{* * *}$ & $246.9^{* * * *}$ & 1.1 & 2.7 & $62.5^{* * *}$ & $5.0^{*}$ & $78.9^{* * * *}$ \\
\hline Severance (S) & $8.4^{*}$ & 1.2 & $27.0^{* * *}$ & $3.3^{\#}$ & 0.01 & 1.6 & $4.7^{*}$ & 1.4 & 1.1 \\
\hline $\mathrm{O} \times \mathrm{S}$ & $23.7^{* * * *}$ & $5.8^{*}$ & $202.4^{* * *}$ & $21.7^{* * *}$ & 0.1 & 0.03 & $4.1^{\#}$ & 0.4 & 1.4 \\
\hline
\end{tabular}

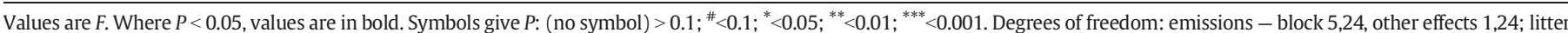
and soil - block 5,36, oil 2,36, severance 1,36, oil $\times$ severance 2,36.
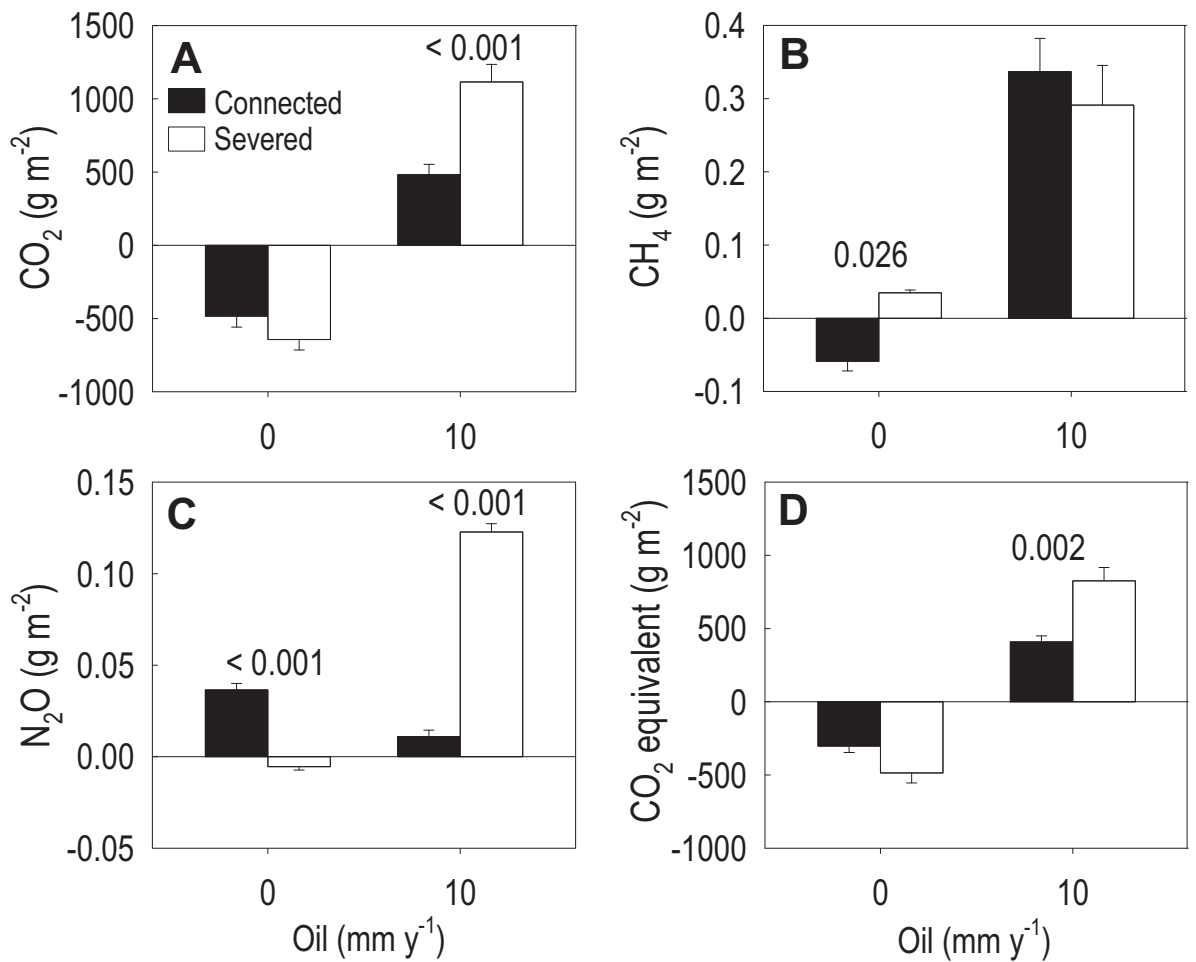

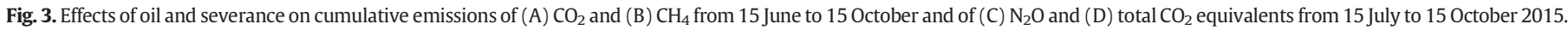

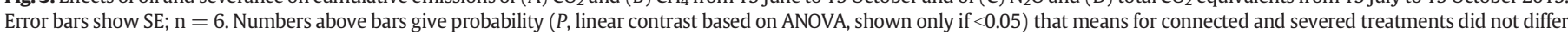
within an oil treatment. See Table 2 for ANOVAs. 


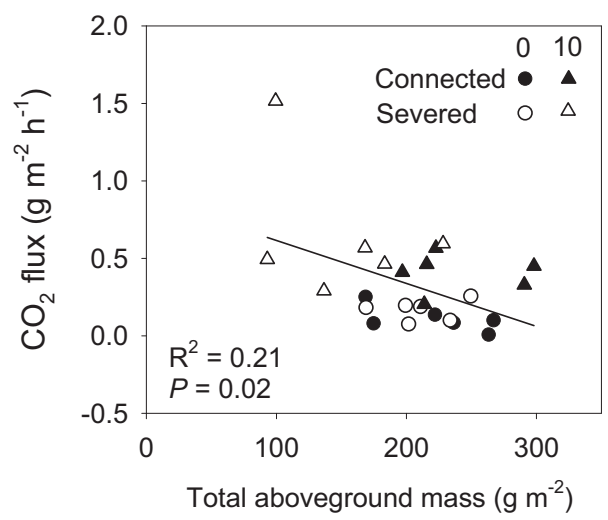

Fig. 4. Linear regression of emission of $\mathrm{CO}_{2}$ measured on October 15 on aboveground dry mass of $P$. australis at the end of the growing season in four severance and oil ( 0 and $10 \mathrm{~mm}$ oil per year) treatment combinations in 2015. $\mathrm{n}=24$.

mass, and increased total emissions of greenhouse gases as measured by cumulative total $\mathrm{CO}_{2}$ equivalents. In treatments where rhizomes were left connected, applying oil did not decrease plant aboveground production and increased total emissions only about half as much as in severed plots. Our results thus strongly supported both the hypothesis that clonal integration in clonal plants can help them to maintain productivity when subjected to patchy deposition of oil and the hypothesis that clonal integration can mitigate the increase in emissions of greenhouse gases associated with oil pollution in vegetated habitats.

Effects of oil on plants were roughly consistent with other studies, as far as can be judged given differences in methods (Dowty et al., 2001;
Ding et al., 2011; Zhu et al., 2013; Judy et al., 2014). For example, Judy et al. (2014) reported that application of $12 \mathrm{~L}$ light crude oil $\mathrm{m}^{-2}$, equivalent to $12 \mathrm{~mm}$, decreased aboveground biomass of $P$. australis by about $30 \%$ in a greenhouse experiment. Dowty et al. (2001) found much greater effects, reduction of aboveground biomass by about $85 \%$ by $10 \mathrm{~mm}$ of similar oil in flooded mesocosms. Ding et al. (2011) applied $2 \mathrm{~mm}$ oil from the Shengli Oil Field to potted plants of another clonal grass from the Yellow River Delta, Aeluropus sinensis, and saw no effect of connection to plants without oil after two months. However, this dose of oil was relatively low. These studies can only be compared to the severed treatments, since they did not include plants in treatments with oil connected to plants in areas without oil.

In a field survey of effects of oilfield seepage in the Yellow River Delta, Zhu et al. (2013) observed that aboveground dry mass of $P$. australis generally decreased as total petroleum hydrocarbons in soil

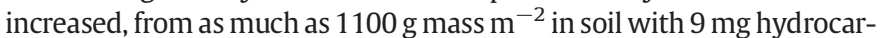
bons $\mathrm{kg}^{-1}$ to as little as $5 \mathrm{~g}$ mass $\mathrm{m}^{-2}$ in soil with $5650 \mathrm{mg}$ hydrocarbons $\mathrm{kg}^{-1}$. Although neither our study nor previous work appears to have specifically measured effect of oil pollution on survival of $P$. australis, such massive reduction in biomass must entail high mortality of shoots. Mortality in the usual sense of death of genetic individuals is hard to determine in plants with extensive clonal growth such as P. australis.

Observed levels of emissions of $\mathrm{CO}_{2}$ and aboveground biomass in the treatment without oil or severance were reasonably consistent with two studies in another area of wetland dominated by P. australis in the Yellow River Delta using eddy covariance (Zhou et al., 2009; Han et al., 2012). Zhou et al. (2009) recorded a cumulative net $\mathrm{CO}_{2}$ uptake of about $200 \mathrm{~g} \mathrm{C} \mathrm{m}^{-2}$ from June to October (about $40 \%$ more than found here) and a net emission of $\mathrm{CO}_{2}$ in November (found here at the last measurement in mid-October). Han et al. (2012) reported net uptake
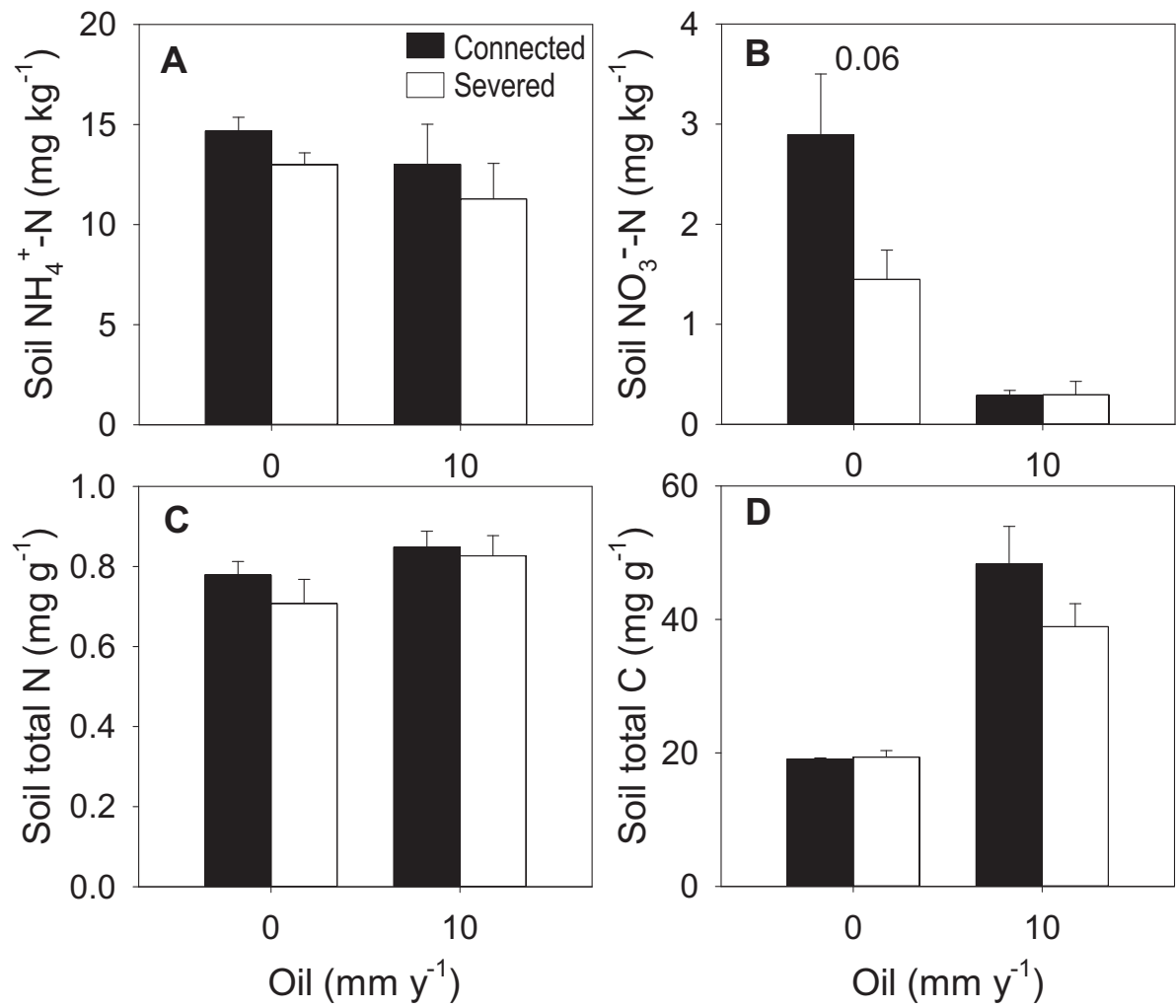

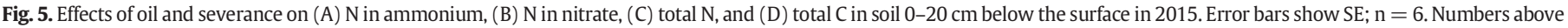

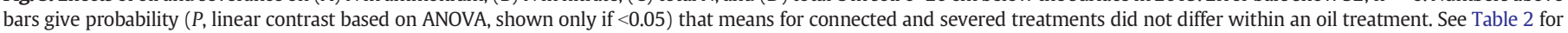
ANOVAs. 
of about $800 \mathrm{~g} \mathrm{CO}_{2} \mathrm{~m}^{-2}$ over the portion of the growing season measured here (about $40 \%$ more than our value) and aboveground mass of about $180 \mathrm{~g} \mathrm{~m}^{-2}$ in mid-October (about 20\% less than our value).

These two previous studies also provide good evidence that ecosystem-level emissions of $\mathrm{CO}_{2}$ are negatively related to plant production in the study system (Zhou et al., 2009; Han et al., 2012). Both studies found a strong, positive correlation between photosynthetically active radiation and net ecosystem aboveground biomass of $P$. australis and net influx of $\mathrm{CO}_{2}$ during the growing season (Zhou et al., 2009; Han et al., 2012). Han et al. (2012) further noted that aboveground biomass of $P$. australis closely predicted net uptake of $\mathrm{CO}_{2}$ during the growing season, and Brix et al. (2001) concluded that maximum standing aboveground biomass correlated well with aboveground productivity in the species in Europe. Results from this study likewise showed a negative relationship between aboveground biomass of $P$. australis and net emission of $\mathrm{CO}_{2}$.

However, results also suggest that aboveground production was not the sole factor in $\mathrm{CO}_{2}$ emissions. Even in plots with similar aboveground biomass of $P$. australis, such as in the plots where rhizomes were left connected, there was a net cumulative uptake of $\mathrm{CO}_{2}$ in the absence of oil but a net emission of $\mathrm{CO}_{2}$ if oil was added. One possible explanation is that oil affected belowground production of $P$. australis more strongly than aboveground production; belowground production in the species may roughly equal aboveground production (Brix et al., 2001). Another possible explanation is that oil addition increased labile carbon in the soil, which in turn stimulated microbial activity. An increase in soil microbial activity may promote soil respiration and release of $\mathrm{CO}_{2}$ (So and Young, 2001; Mbadinga et al., 2011).

Reduced availability of oxygen in the soil may explain the observed, positive effects of oil on emission of $\mathrm{CH}_{4}$. Deposition of oil can restrict the movement of oxygen into the soil, directly and also indirectly via diffusion within plant stems, and favor anaerobic, microbial decomposition of soil organic matter leading to methanogenesis (Pezeshki et al., 2000; Armstrong et al., 2009; Liu and Greaver, 2009; Aronson and Helliker, 2010). In addition, some hydrocarbons in oil can be abiotically converted to $\mathrm{CH}_{4}$ under anaerobic conditions (So and Young, 2001; Widdel and Rabus, 2001; Mbadinga et al., 2011). The relatively low concentration of seen in oiled soils is also consistent with a negative effect of oil on soil oxygen. The low amount of $\mathrm{NO}_{3}^{-}$compared to $\mathrm{NH}_{4}^{+}$even in plots without oil indicates that soils were already low in oxygen, as might be expected in a wetland. Rhizomes and roots can aerate soil (e.g., Armstrong et al., 2009), and the failure of severance to affect emission of $\mathrm{CH}_{4}$ may thus indicate that clonal integration did not help to alleviate oxygen stress in oiled soils because it did not promote underground production. This is consistent with the observed lack of effect of connection on the concentration of $\mathrm{NO}_{3}^{-}$in oiled soils. Connection did have a marginally significant positive effect on the concentration of $\mathrm{NO}_{3}^{-}$in soils without oil, mirrored by the nominal negative effect $(P>0.1)$ of connection on emission of $\mathrm{CH}_{4}$. The positive effect of oil on total $\mathrm{C}$ in soil may simply be due to the $\mathrm{C}$ in the added oil.

The effect of soil oxygen level on $\mathrm{N}_{2} \mathrm{O}$ emissions is more complex, since denitrifying bacteria reduce $\mathrm{NO}_{3}^{-}$to $\mathrm{N}_{2} \mathrm{O}$ under anaerobic conditions, while nitrifying bacteria oxidize $\mathrm{NH}_{4}^{+}$to $\mathrm{N}_{2} \mathrm{O}$ under aerobic ones (e.g., Weier et al., 1993; Dalal et al., 2003; Butterbach-Bahl et al., 2013). The strong interactive effect of oil and severance on emission of $\mathrm{N}_{2} \mathrm{O}$ did not match concentrations of $\mathrm{NH}_{4}^{+}$or of $\mathrm{N}_{2} \mathrm{O}$ in soils. Application of $10 \mathrm{~mm}$ oil per year more than doubled total $\mathrm{C}$ in soil with little effect on total $\mathrm{N}$, and addition of decomposable organic compounds low in $\mathrm{N}$ when oxygen is also low tends to promote denitrification (Liu and Greaver, 2009). This fits with the relatively low concentration of $\mathrm{NO}_{3}^{-}$ and the high emission of $\mathrm{N}_{2} \mathrm{O}$ in the severed and oiled treatment, but does not explain the low emission of $\mathrm{N}_{2} \mathrm{O}$ in the connected, oiled treatment.

One important question is how representative these results are. Effects of crude oil on wetland plants differ greatly between types of oil, plant species, and timing and mode of deposition (Pezeshki et al., 2000; Dowty et al., 2001; Pezeshki et al., 2001; Judy et al., 2014); the heavy, unweathered crude oil used in this study is probably less toxic than most light or weathered crude oils. Other factors not tested here, such as effect of water level (Dinsmore et al., 2009; Berglund and Berglund, 2011), can also exercise major controls on emissions of greenhouse gases from wetlands. Although $\mathrm{CO}_{2}$ accounted for nearly all total $\mathrm{CO}_{2}$ equivalents and thus global warming potential in this study, emission of $\mathrm{CH}_{4}$ can determine whether some wetlands dominated by P. australis are a net sink or source of global warming potential (Brix et al., 2001).

A second important question is whether effects of clonal integration on greenhouse gas emissions from oil deposition are significant at the ecosystem level. Clonal integration can mitigate promotion of greenhouse gas emissions by oil deposition only when plants subject to deposition are connected to plants that are not. This is likely at the edge of a zone or patch of deposition but probably not $>10 \mathrm{~m}$ inside a patch. Combined data on the spatial patterning of clones and oil deposition could provide a basis for modeling effects of clonal integration on emissions at the ecosystem level. Some indirect support for this approach in wetlands dominated by P. australis is provided by Zhu et al. (2013), who suggested that remote sensing of vegetation could estimate oil contamination in one such wetland. Significant effects at the ecosystem level could potentially scale up further, since wetlands play an important role in worldwide emissions of greenhouse gases (Brix et al., 2001; Le Mer and Roger, 2001; Whiting and Chanton, 2011), and since severe disturbance may increase their contribution to global warming (Hirota et al., 2005; Page and Dalal, 2011).

\section{Conclusions}

Our study provides the first experimental evidence that clonal integration in plants can reduce greenhouse gas emissions. The ability of clonal integration to both help maintain plant productivity and reduce greenhouse gas emissions at a site polluted with oil provides new evidence for the general hypothesis that traits that help plant species resist environmental stress can mitigate the increase in greenhouse gas emissions associated with the increase in stress. The trait, species, and system studied here are of general interest in themselves because of their widespread nature. $P$. australis is a very abundant species, and may become more so in response to global warming (Zhong et al., 2014). Moreover, clonal plants appear to be particularly abundant in wetlands, where single clonal species often form large, nearly pure stands (Song and Dong, 2002; Sosnová et al., 2010; Klimešová and Herben, 2015; Wang et al., 2020). Testing whether the observed interaction between clonal integration and oil deposition scales up and how it may vary between species and systems seems a worthwhile direction for further study of the interplay between community structure and global change.

\section{CRediT authorship contribution statement}

Qing-Ye Yuan: Investigation, Data curation, Formal analysis, Writing - original draft. Peter Alpert: Writing - review \& editing. Jing An: Investigation, Data curation. Jun-Qin Gao: Investigation, Methodology. Guang-Xuan Han: Methodology, Resources. Fei-Hai Yu: Conceptualization, Supervision, Methodology, Writing - review \& editing.

\section{Declaration of competing interest}

The authors declare that they have no known competing financial interests or personal relationships that could have appeared to influence the work reported in this paper.

\section{Acknowledgements}

We thank Bi-Cheng Dong for assistance with data analysis. This work was supported by the National Natural Science Foundation of China (31870610 and 31761123001 ) and the Ten-Thousand-Talent Program 
of Zhejiang Province (2018R52016) and the Joint Fund of Zhejiang Provincial Natural Science Foundation (LTZ20C030001).

\section{Appendix A. Supplementary data}

Supplementary data to this article can be found online at https://doi. org/10.1016/j.scitotenv.2020.140007.

\section{References}

Alpert, P., 1991. Nitrogen sharing among ramets increases clonal growth in Fragaric chiloensis. Ecology 72, 69-80.

Alpert, P., 1999. Clonal integration in Fragaria chiloensis differs between populations: ramets from grassland are selfish. Oecologia 120, 69-76.

Alpert, P., Mooney, H.A., 1986. Resource sharing among ramets in the clonal herb, Fragaria chiloensis. Oecologia 70, 227-233.

Amsberry, L., Baker, M.A., Ewanchuk, P.J., Bertness, M.D., 2000. Clonal integration and the expansion of Phragmites australis. Ecol. Appl. 10, 1110-1118.

Armstrong, J., Keep, R., Armstrong, W., 2009. Effects of oil on internal gas transport, radial oxygen loss, gas films and bud growth in Phragmites australis. Ann. Bot. 103, 333-340.

Aronson, E.L., Helliker, B.R., 2010. Methane flux in non-wetland soils in response to nitrogen addition: a meta-analysis. Ecology 91, 3242-3251.

Berglund, Ö., Berglund, K., 2011. Influence of water table level and soil properties on emissions of greenhouse gases from cultivated peat soil. Soil Biol. Biochem. 43, 923-931.

Brix, H., Sorrell, B.K., Lorenzen, B., 2001. Are Phragmites-dominated wetlands a net source or net sink of greenhouse gases? Aquat. Bot. 69, 313-324.

Butterbach-Bahl, K., Baggs, E.M., Dannenmann, M., Kiese, R., Zechmeister-Boltenstern, S., 2013. Nitrous oxide emissions from soils: how well do we understand the processes and their controls? Phil. Trans. Roy. Soc. B Biol. Sci. 368, 91-97.

Clevering, O.A., Lissner, J., 1999. Taxonomy, chromosome numbers, clonal diversity and population dynamics of Phragmites australis. Aquat. Bot. 64, 185-208.

Cui, B.S., Yang, Q.C., Yang, Z.F., Zhang, K.J., 2009. Evaluating the ecological performance of wetland restoration in the Yellow River Delta, China. Ecol. Eng. 35, 1090-1103.

Dalal, R.C., Wang, W.J., Robertson, G.P., Parton, W.J., 2003. Nitrous oxide emission from Australian agricultural lands and mitigation options: a review. Aust. J. Soil Res. 41, 165-195.

Ding, W.J., Liu, J., Wu, D.Q., Wang, Y., Chang, C.C., Wang, R.Q., 2011. Salinity stress modulates habitat selection in the clonal plant Aeluropus sinensis subjected to crude oil deposition. J. Torrey Bot. Soc. 138, 262-271.

Dinsmore, K.J., Skiba, U.M., Billett, M.F., Rees, R.M., 2009. Effect of water table on greenhouse gas emissions from peatland mesocosms. Plant Soil 318, 229-242.

Dong, B.C., Alpert, P., Zhang, Q., Yu, F.H., 2015. Clonal integration in homogeneous environments increases performance of Alternanthera philoxeroides. Oecologia 179 393-403.

Dongwook, L., Kido, P., Changyoung, P., et al., 2007. N use efficiency and nitrate leaching by fertilization level and film mulching in sesame cultivated upland. Korean J. Crop Sci. 52, 296-302.

Dowty, R.A., Shaffer, G.P., Hester, M.W., Childers, G.W., Campo, F.M., Greene, M.C., 2001 Phytoremediation of small-scale oil spills in fresh marsh environments: a mesocosm simulation. Mar. Environ. Res. 52, 195-211.

Eller, F., Skálová, H., Caplan, J.S., Bhattarai, G.P., Burger, M.K., Cronin, J.T., Guo, W.Y., Guo, X., Hazelton, E.L., Kettenring, K.M., 2017. Cosmopolitan species as models for ecophysiological responses to global change: the common reed Phragmites australis. Front. Plant Sci. 8, 1833

Fahey, T.J., Siccama, T.G., Driscoll, C.T., et al., 2005. The biogeochemistry of carbon at Hubbard Brook. Biogeochemistry 75, 109-176.

Han, G.X., Yang, L.Q., Yu, J.B., Wang, G.M., Mao, P.L., Gao, Y.J., 2012. Environmental controls on net ecosystem $\mathrm{CO}_{2}$ exchange over a reed (Phragmites australis) wetland in the Yellow River Delta, China. Estuar. Coasts 36, 401-413.

Haslam, S.M., 1969. The development and emergence of buds in Phragmites communis Trin. Ann. Bot. 33, 289-301.

He, W.M., Yu, F.H., Zhang, L.L., 2010. Physiological integration impacts nutrient use and stoichiometry in three clonal plants under heterogeneous habitats. Ecol. Res. 25 967-972.

He, W.M., Alpert, P., Yu, F.H., Zhang, L.-L., Dong, M., 2011. Reciprocal and coincident patchiness of multiple resources differentially affect benefits of clonal integration in two perennial plants. J. Ecol. 99, 1202-1210.

Hirota, M., Tang, Y.H., Hu, Q.W., et al., 2005. The potential importance of grazing to the fluxes of carbon dioxide and methane in an alpine wetland on the Qinghai-Tibetan Plateau. Atmos. Environ. 39, 5255-5259.

Hutchings, M.J., Wijesinghe, D.K., 2008. Performance of a clonal species in patchy environments: effects of environmental context on yield at local and whole-plant scales. Evol. Ecol. 22, 313-324.

Huxman, T.E., Snyder, K.A., Tissue, D., et al., 2004. Precipitation pulses and carbon fluxes in semiarid and arid ecosystems. Oecologia 141, 254-268.

IPCC, 2014. Summary for policymakers. In: Pachauri, R.K., Meyer, L.A., et al. (Eds.), Climate Change 2014: Synthesis Report. Contribution of Working Groups I, II and III to the Fifth Assessment Report of the Intergovernmental Panel on Climate Change. IPCC, Geneva, Switzerland, p. 151.

Ji, G.D., Sun, T.H., Ni, J.R., 2007. Impact of heavy oil-polluted soils on reed wetlands. Ecol. Eng. 29, 272-279.
Judy, C.R., Graham, S.A. Lin, QX, Hou, A. Mendelssohn, LA 2014. Impacts of Macondo oil from Deepwater Horizon spill on the growth response of the common reed Phragmites australis: a mesocosm study. Mar. Pollut. Bull. 79, 69-76.

Klimešová, J., Herben, T., 2015. Clonal and bud bank traits: patterns across temperate plant communities. J. Veg. Sci. 26, 243-253.

de Kroon, H., van Groenendael, J., 1997. The Ecology and Evolution of Clonal Plants. Backhuys Publishers, Leiden, The Netherlands.

Kuenzer, C., Ottinger, M., Liu, G.H., Sun, B., Baumhauer, R., Dech, S., 2014. Earth observation-based coastal zone monitoring of the Yellow River Delta: dynamics in China's second largest oil producing region observed over four decades. Appl. Geogr. 55, 92-107.

Lambertini, C., Gustafsson, M.H.G., Frydenberg, J., Speranza, M., Brix, H., 2008. Genetic diversity patterns in Phragmites australis at the population, regional and continental scales. Aquat. Bot. 88, 160-170.

Le Mer, J., Roger, P., 2001. Production, oxidation, emission and consumption of methane by soils: a review. Eur. J. Soil Biol. 37, 25-50.

Li, ZJ., Fan, D.Y Chen, F. Yuan, QY Chow, WS, Xie, Z.Q 2015. Physiological integration enhanced the tolerance of Cynodon dactylon to flooding. Plant Biol. 17, 459-465.

Lin, Q., Mendelssohn, I.A., 2012. Impacts and recovery of the Deepwater Horizon oil spill on vegetation structure and function of coastal salt marshes in the northern Gulf of Mexico. Environ. Sci. Technol. 46, 3737-3743.

Lin, H.F., Alpert, P., Zhang, Q., Yu, F.H., 2018. Facilitation of amphibious habit by physiological integration in the clonal, perennial, climbing herb Ipomoea aquatica. Sci. Total Environ. 618, 262-268.

Liu, L.L., Greaver, T.L., 2009. A review of nitrogen enrichment effects on three biogenic GHGs: the $\mathrm{CO}_{2}$ sink may be largely offset by stimulated $\mathrm{N}_{2} \mathrm{O}$ and $\mathrm{CH}_{4}$ emission. Ecol. Lett. 12, 1103-1117.

Liu, D., Fang, S., Tian, Y., Chang, S.X., 2014a. Nitrogen transformations in the rhizosphere of different tree types in a seasonally flooded soil. Plant Soil Environ. 60, 249-254.

Liu, S.W., Zhao, C., Zhang, Y.J., et al., 2014b. Annual net greenhouse gas balance in a halophyte (Helianthus tuberosus) bioenergy cropping system under various soil practices in Southeast China. Global Change Biol. Bioener. 7, 690-703.

Luo, F.L., Xing, Y.P., Li, C.Y., Yu, F.H., 2017. Clonal integration facilitates spread of Paspalum paspaloides from terrestrial to cadmium contaminated aquatic habitat. Plant Biol. 19, 859-867.

Martin, A.C., Zallinger, J., 1972. Weeds. Golden Press, Racine, WI, The USA.

Mbadinga, S.M., Wang, L.Y., Zhou, L., Liu, J.F., Gu, J.D., Mu, B.Z., 2011. Microbial communities involved in anaerobic degradation of alkanes. Int. Biodeterior. Biodegrad. 65, $1-13$.

Mendelssohn, I.A., Andersen, G.L., Baltz, D., et al., 2012. Oil impacts on coastal wetlands: implications for the Mississippi River Delta ecosystem after the Deepwater Horizon oil spill. Bioscience 62, 562-574.

Merbold, L., Eugster, W., Stieger, J., Zahniser, M., Nelson, D., Buchmann, N., 2014. Greenhouse gas budget $\left(\mathrm{CO}_{2}, \mathrm{CH}_{4}\right.$ and $\left.\mathrm{N}_{2} \mathrm{O}\right)$ of intensively managed grassland following restoration. Glob. Chang. Biol. 20, 1913-1928.

Minchinton, T.E., Bertness, M.D., 2003. Disturbance-mediated competition and the spread of Phragmites australis in a coastal marsh. Ecol. Appl. 13, 1400-1416.

Mo, Y., Deng, Z.H., Gao, J.Q., Guo, Y.X., Yu, F.H., 2015. Does richness of emergent plants affect $\mathrm{CO}_{2}$ and $\mathrm{CH}_{4}$ emissions in experimental wetlands? Freshw. Biol. 60, 1537-1544.

Nie, M., Yang, Q., Jiang, L.F., Fang, C.M., Chen, J.K., Li, B., 2010. Do plants modulate biomass allocation in response to petroleum pollution? Biol. Lett. 6, 811-814.

Page, K.L., Dalal, R.C., 2011. Contribution of natural and drained wetland systems to carbon stocks, $\mathrm{CO}_{2}, \mathrm{~N}_{2} \mathrm{O}$, and $\mathrm{CH}_{4}$ fluxes: an Australian perspective. Soil Res. 49, 377-388.

Pennings, S.C., Grant, M.B., Bertness, M.D., 2005. Plant zonation in low-latitude salt marshes: disentangling the roles of flooding, salinity and competition. J. Ecol. 93, 159-167.

Pezeshki, S.R., Hester, M.W., Lin, Q., Nyman, J.A., 2000. The effects of oil spill and clean-up on dominant US Gulf coast marsh macrophytes: a review. Environ. Pollut. 108, 129-139.

Pezeshki, S.R., Delaune, R.D., Jugsujinda, A., 2001. The effects of crude oil and the effectiveness of cleaner application following oiling on US Gulf of Mexico coastal marsh plants. Environ. Pollut. 112, 483-489.

Roiloa, S.R., Retuerto, R., 2012. Clonal integration in Fragaria vesca growing in metalpolluted soils: parents face penalties for establishing their offspring in unsuitable environments. Ecol. Res. 27, 95-106.

Saleem, H., Arslon, M., Rehman, K., Tahseen, R., Afzal, M., 2019. Phragmites australis - a helophytic grass - can establish successful partnership with phenol-degrading bacteria in a floating treatment wetland. Saudi J. Biol. Sci. 26, 1179-1186.

Salzman, A.G., Parker, M.A., 1985. Neighbors ameliorate local salinity stress for a rhizomatous plant in a heterogeneous environment. Oecologia 65, 273-277.

Shumway, S.W., 1995. Physiological integration among clonal ramets during invasion of disturbance patches in a new England salt marsh. Ann. Bot. 76, 225-233.

Silliman, B.R., Grosholz, E., Bertness, M.D., 2009. Human Impacts on Salt Marsh Ecosystems: Causes, Consequences and Solutions. University of California Press, Berkeley, CA, The USA

Snyder, C.S., Bruulsema, T.W., Jensen, T.L., Fixen, P.E., 2009. Review of greenhouse gas emissions from crop production systems and fertilizer management effects. Agric. Ecosyst. Environ. 133, 247-266.

So, C.M., Young, L.Y., 2001. Anaerobic biodegradation of alkanes by enriched consortia under four different reducing conditions. Environ. Toxicol. Chem. 20, 473-478.

Song, M.H., Dong, M., 2002. Clonal plants and plant species diversity in wetland ecosystems in China. J. Veg. Sci. 13, 237-244.

Song, Y.B., Yu, F.H., Keser, L.H., Dawson, W., Fischer, M., Dong, M., van Kleunen, M., 2013. United we stand, divided we fall: a meta-analysis of experiments on clonal integration and its relationship to invasiveness. Oecologia 171, 317-327. 
Sosnová, M., Diggelen, R.V., Klimešová, J., 2010. Distribution of clonal growth forms in wetlands. Aquat. Bot. 92, 33-39.

Towprayoon, S., Smakgahn, K., Poonkaew, S., 2005. Mitigation of methane and nitrous oxide emissions from drained irrigated rice fields. Chemosphere 59, 1547-1556.

Wang, X.H., Yu, J.B., Zhou, D., Dong, H.F., Li, Y.Z., Lin, Q.X., Guan, B., Wang, Y.L., 2012. Vegetative ecological characteristics of restored reed (Phragmites australis) wetlands in the Yellow River Delta, China. Environ. Manag. 49, 325-333.

Wang, J., Liu, L.L., Wang, X., Chen, Y.W., 2015. The interaction between abiotic photodegradation and microbial decomposition under ultraviolet radiation. Glob. Chang. Biol. 21, 2095-2104.

Wang, Y.J., Müller-Schärer, H., van Kleunen, M., Cai, A.M., Zhang, P., Yan, R., Dong, B.C., Yu, F.H., 2017. Invasive alien plants benefit more from clonal integration in heterogeneous environments than natives. New Phytol. 216, 1072-1078.

Wang, M.Z., Li, H.L., Li, J.M., Yu, F.H., 2020. Correlations between genetic, epigenetic and phenotypic variation of an introduced clonal herb. Heredity 124, 146-155.

Weier, K.L., Doran, J.W., Power, J.F., Walters, D.T., 1993. Denitrification and the dinitrogen/ nitrous oxide ratio as affected by soil water available carbon and nitrate. Soil Sci. Soc. Am. J. 57, 66-72.

Whiting, G.J., Chanton, J.P., 2011. Greenhouse carbon balance of wetlands: methane emission versus carbon sequestration. Tellus Ser. B Chem. Phys. Meteorol. 53, 521-528.

Widdel, F., Rabus, R., 2001. Anaerobic biodegradation of saturated and aromatic hydrocarbons. Curr. Opin. Biotechnol. 12, 259-276.

Wilson, A.M., Evans, T., Moore, W., Schutte, C.A., Joye, S.B., Hughes, A.H., Anderson, J.L., 2015. Groundwater controls ecological zonation of salt marsh macrophytes. Ecology $96,840-849$.

Xie, T., Liu, X.H., Sun, T., 2011. The effects of groundwater table and flood irrigation strategies on soil water and salt dynamics and reed water use in the Yellow River Delta, China. Ecol. Model. 222, 241-252.
Xu, X.G., Lin, H.P., Fu, Z.Y., 2004. Probe into the method of regional ecological risk assessment-a case study of wetland in the Yellow River Delta in China. J. Environ. Manag. 70, 253-262.

Xu, C.Y., Schooler, S.S., Van Klinken, R.D., 2010. Effects of clonal integration and light availability on the growth and physiology of two invasive herbs. J. Ecol. 98, 833-844.

Yang, Z.F., Wang, L.L., Niu, J.F., Wang, J.Y., Shen, Z.Y., 2008. Pollution assessment and source identifications of polycyclic aromatic hydrocarbons in sediments of the Yellow River Delta, a newly born wetland in China. Environ. Monit. Assess. 158, 561-571.

Yavitt, J.B., 1997. Methane and carbon dioxide dynamics in Typha latifolia (L.) wetlands in Central New York state. Wetlands 17, 394-406.

Yu, F.H., Dong, M., Krusi, B, 2004. Clonal integration helps Psammochloa villosa survive sand burial in an inland dune. New Phytol. 162, 697-704.

Yu, F.H., Wang, N., He, W.M, Chu, Y., Dong, M., 2008. Adaptation of rhizome connections in drylands: increasing tolerance of clones to wind erosion. Ann. Bot. 102, 571-577.

Zhang, Y.C., Zhang, Q.Y., Yirdaw, E., Luo, P., Wu, N., 2008. Clonal integration of Fragaria orientalis driven by contrasting water availability between adjacent patches. Bot. Stud. 49, 373-383.

Zhong, Q.C., Gong, J.N., Wang, K.Y., Zhang, C., 2014. Effects of 3-year air warming on growth of two perennial grasses (Phragmites australis and Imperata cylindrica) in a coastal salt marsh reclaimed for agriculture. Aquat. Bot. 117, 18-26.

Zhou, L., Zhou, G.S., Jia, Q.Y., 2009. Annual cycle of $\mathrm{CO}_{2}$ exchange over a reed (Phragmites australis) wetland in Northeast China. Aquat. Bot. 91, 91-98.

Zhu, L.H., Zhao, X.C., Lai, L.M., et al., 2013. Soil TPH concentration estimation using vegetation indices in an oil polluted area of eastern China. PLoS One 8, e54028. 